\title{
Comments on: An Undergraduate Surgery Interest Group: Introducing Premedical Students to the Practice of Surgery [Letter]
}

This article was published in the following Dove Press journal:

Advances in Medical Education and Practice

\section{Adham Chakhachiro (1) \\ Faculty of Medicine, Imperial College London, London, UK}

Correspondence: Adham Chakhachiro Faculty of Medicine, Imperial College London, South Kensington, London SW7 2AZ, UK

Email adham.chakhachirol5@imperial.ac.uk

\section{Dear editor}

The study conducted by Vakayil et $\mathrm{al}^{1}$ regarding an undergraduate surgery interest group (USIG) to augment interest in a surgical career was read with great interest. Their findings that the USIG strengthened students understanding and interests in a surgical career is promising as surgical career matriculation and occupancy rates decrease. ${ }^{1,2}$ However, the value of implementing such early educational initiatives remains unknown and it's hard to conclude whether to encourage other institutions to incorporate similar initiatives.

The study did not evaluate whether any of the participants of the USIG actually went on to enrol in a surgical residency programme. Only then would the true value of bolstering interest and tackling the low occupancy rates in surgical residency programmes be proved. It would be interesting to conduct this study over a longer time period and for the authors of the study to follow up on the students' future career paths. This would also help ascertain whether the benefits of the workshops were sustained, and true interest was promoted. The questionnaires conducted were only distributed on two events, this merely shows the efficacy of those two events and not the USIG as a whole. Perhaps conducting the surveys at the beginning and end of the academic year will yield more robust and reliable results regarding the impact of this initiative and the workshops as a whole instead of individual workshops.

In addition, the demographic of the USIG is interesting to note. Surprisingly females made up the majority of the group at $75 \%$. This is in stark contrast to the percentage of female surgeons at only $24 \%{ }^{3}$. This drop could be due to a lack of female surgical mentors. Furthermore, only $7.14 \%$ of students initially did not have an interest in pursuing a career in surgery with over $75 \%$ of the students very much interested in surgery. To determine the true benefits of this initiative, it would be interesting to see how the perceptions of those not interested in surgery change over time. Whist retaining those with an interest in surgery is important, encouraging students who are uncertain or uninterested in surgery is also key.

It's interesting to note that various studies by scholars have shown that preference of students' career specialties remains relatively stable across medical school and does not change much. ${ }^{4}$ Further research is needed to confirm whether preference correlates with final career speciality choice. This finding begs the questions whether such initiatives will help in the grand scheme of the falling number surgeons. Having 
said that, offering the opportunity for surgical mentorship has shown promising results. ${ }^{5}$

To conclude, the study conducted by Vakayil et al touches upon an imperative issue regarding the falling matriculation rates and increasing attrition rates of surgical residency programmes. The study would have benefited from investigating whether students in the USIG entered surgical residency and whether students not initially interested in surgery changed opinion. More research needs to be conducted to fully determine the benefits of such initiatives to undergraduate students.

\section{Disclosure}

The authors report no conflicts of interest in this communication.

\section{References}

1. Vakayil V, Chandrashekar M, Hedberg J, et al. An undergraduate surgery interest group: introducing premedical students to the practice of surgery. Adv Med Educ Pract. 2020;11:339-349. Dove Press. doi:10.2147/AMEP.S245234.

2. NRMP. National Resident Matching Program Historical Reports. NRMP 1984 - 2002.

3. Sanfey HA, Saalwachter-Schulman AR, Nyhof-Young JM, Eidelson B, Mann BD. Influences on medical student career choice: gender or generation? Arch Surg. 2006;141(11):1086-1094. doi:10.1001/ archsurg.141.11.1086

4. Scott I, Gowans M, Wright B, Brenneis F. Stability of medical student career interest. Acad Med. 2012;87(9):1260-1267. Lippincott Williams and Wilkins. doi:10.1097/ACM.0b013e31826291fa

5. Giantini Larsen AM, Pories S, Parangi S, Robertson FC. Barriers to pursing a career in surgery. Ann Surg. 2019;1. Ovid Technologies (Wolters Kluwer Health)

Dove Medical Press encourages responsible, free and frank academic debate. The content of the Advances in Medical Education and Practice 'letters to the editor' section does not necessarily represent the views of Dove Medical Press, its officers, agents, employees, related entities or the Advances in Medical Education and Practice editors. While all reasonable steps have been taken to confirm the content of each letter, Dove Medical Press accepts no liability in respect of the content of any letter, nor is it responsible for the content and accuracy of any letter to the editor.

\section{Publish your work in this journal}

Advances in Medical Education and Practice is an international, peerreviewed, open access journal that aims to present and publish research on Medical Education covering medical, dental, nursing and allied health care professional education. The journal covers undergraduate education, postgraduate training and continuing medical education including emerging trends and innovative models linking education, research, and health care services. The manuscript management system is completely online and includes a very quick and fair peer-review system. Visit http://www.dovepress.com/testimonials.php to read real quotes from published authors. 